\title{
Pengaruh Frekuensi Pemberian Pakan dan Periode Pemberian Pakan terhadap Hematologis Ayam Buras Super Umur 3 - 12 Minggu
}

\author{
Effect of Feeding Frequency and Feeding Period on Hematologic of Crossbred Native Chicken \\ Aged 3 - 12 weeks
}

\section{G. D. Abdullah, E. Suprijatna, dan Isroli}

Faculty of Animal Husbandry and Agriculture, University of Diponegoro, Semarang Email:galangdisa@gmail.com

\begin{abstract}
This research was conducted to know the hematologic of crossbred native chicken given feeding frequency and feeding periods treatments. The materials used in the study were 252 crossbred native chicks unsex with an average body weights $37.88 \pm 1.98 \mathrm{~g} \mathrm{(CV} \mathrm{:} \mathrm{5.02 \% ).} \mathrm{The} \mathrm{research} \mathrm{using} \mathrm{commercial} \mathrm{feed} \mathrm{from} \mathrm{PT} \mathrm{Charoen} \mathrm{Pokphand,} \mathrm{B11S}$ for starter and B12S for finisher. This research used plot split plot with 3 levels of feeding frequency (F1 = once feeding frequency, F2 = twice feeding frequency, F3 = thrice feeding frequency) as main plot and 3 levels of feeding period $(\mathrm{P} 1=14 \mathrm{~h}, \mathrm{P} 2=16 \mathrm{~h}, \mathrm{P} 3=18 \mathrm{~h})$ as sub plotin 4 replications sp there was 36 experimental units that each unit consist 7 birds. Data were analyzed using analysis of variance and $\mathrm{F}$ test at $5 \%$ level, then using duncan for the significant. The result show that feeding period significantly effect $(\mathrm{p}<0.05)$ toward glucose, there was interaction effect of feeding frequency and feeding period $(\mathrm{p}<0.05)$ on $\mathrm{H} / \mathrm{L}$ ratio, but feeding frequency and feeding period didn't significantly effect and each factor didn't effect on hemoglobin, red blood cells and white blood cells.
\end{abstract}

Key words : frequency, time periods, hematologic, cressbred native chicken

\section{ABSTRAK}

Penelitian ini dilakukanuntuk mengetahui hematologi pada ayam buras super yang diberi perlakuan frekuensi pemberian pakan dan periode pemberian pakan. Materi yang digunakan dalam penelitian ini yaitu 252 ekor anak ayam buras super unsex dengan rata-rata bobot badan 37,88 $\pm 1,98 \mathrm{~g}$ (CV : 5,02\%). Penelitian menggunakan pakan komersial dari PT Charoen Pokphand, periode starter B11S dan periode finisher B12S. Penelitian ini menggunakan rancangan split plot dengan main plot 3 frekuensi pemberian pakan dan sub plot 3 taraf periode pemberian pakan dengan 4 ulangan sehingga menggunakan 36 unit percobaan, masing-masing unit percobaan berisi 7 ekor. Perlakuan yang dilakukan adalah : faktor $\mathrm{F}$ frekuensi pemberian pakan (1x/hari, 2x/hari, 3x/hari) dan faktor Periode pemberian pakan (14 jam, 16 jam, dan 18 jam). Data penelitian yang diperoleh kemudian di analisis ragam menggunakan uji $F$ dengan taraf $5 \%$ dan dilanjutkan uji Duncan untuk data yang berbeda nyata. Hasil penelitian menunjukkan bahwa perlakuan periode berpengaruh nyata $(p<0,05)$ terhadap kadar glukosa darah, terdapat pengaruh interaksi antara frekuensi pemberian pakan dengan periode pemberian pakan $(p<0,05)$ terhadap rasio $H / L$, tidak ada pengaruh interaksi $(\mathrm{p}<0,05)$ frekuensi dan periode pemberian pakan serta masing masing faktor tidak berpengaruh terhadap hemoglobin, eritrosit dan leukosit.

Kata Kunci : Frekuensi, periode, hematologi, ayam Buras Super

\section{PENDAHULUAN}

Ayam Buras Super merupakan hasil persilangan antara ayam Buras dengan ayam Ras untuk tujuan meningkatkan produksi daging ayam. Persilangan tersebut berkaitan dengan permintaan daging ayam Kampung yang cukup tinggi namun produksinya masih rendah mengingat waktu yang dibutuhkan untuk pemliharaan ayam Kampung sampai siap jual cukup lama. Data Kementan (2015) menunjukkan bahwa konsumsi daging ayam Buras 2013 - 2015 meningkat $11,30 \%$ tetapi produktivitas daging menurun 6,20\%. Ayam Buras Super yang mendapat pakan bermutu baik akan mampu mencapai bobot ideal ayam Kampung yang berumur 5-6 bulan dalam umur 8 minggu (Abun et al., 2007). Dalam usaha 
peternakan salah satu hal yang sangat menentukan produktivitas ternak yaitu manajemen pemberian pakan yang efisien. Hal ini berkaitan dengan suhu lingkungan di Indonesia yang memiliki iklim tropis dimana suhu dapat mengalami fluktuasi. Suhu udara di daerah tropis dapat mencapai titik terendah pada jam 05.00-06.00 pagi sebesar $19^{\circ} \mathrm{C}$ dan terus naik hingga mencapi puncak pada jam 12.00-13.00 sebesar $32,2^{0} \mathrm{C}$ (Hafni et al., 2015).

Berkaitan dengan fluktuasi suhu tersebut maka perlu diterapkan manajemen frekuensi dan periode pemberian pakan. Frekuensi pemberian pakan berkaitan dengan kesempatan ayam untuk mengakses pakan di saat kondisi lingkungan termasuk thermoneutral zone. Nutrien pakan mampu dimanfaatkan dengan efisien untuk pembentukan jaringan saat ayam dalam comfort zone. Saat heat stress mengakibatkan terganggunya metabolisme tubuh karena ayam melakukan usaha pembongkaran energi untuk mengurangi panas tubuh. Hal tersebut mampu memicu kenaikan pada glukosa darah (Abioja et al., 2014). Karena kebutuhan energi untuk hidup pokok berkurang akibat kenaikan temperatur lingkungan, ayam akan mengurangi konsumsi ransum sebagai upaya untuk termoregulasi (Filho et al., 2005).

Periode pemberian pakan perlu diatur didasarkan oleh pemberikan akses pakan lebih lama saat kondisi lingkungan dalam keadaan nyaman untuk ayam. Panjang pendeknya periode menentukan berapa lama ayam dapat mengoptimalkan nutrien dari ransum sehingga mampu dimanfaatkan secara efisien. Shariatmadari (2011) menyatakan bahwa perencanaan program pemberian pakan diperlukan memperhatikan fisiologi lingkungan seperti temperature dan kelembaban. Selama periode heat stress ayam akan mengalami gangguan kecernaan terutama tingkat kecernaan protein dan asam amino untuk pertumbuhan (Al-Aqil et al., 2009). Batas toleransi ayam terhadap lamanya terekspos suhu tinggi sehingga meyebabkan cekaman panas adalah 6 jam, diatas waktu tersebut dapat menurunkan performa ayam (Toplu et al., 2012). Zulkifli et al. (2000) melaporkan bahwa tingkat stress ayam jangka pendek dapat dilihat dari rasio heterofil/limfosit, dimana saat heat stress dapat meningkatkan persentase heterofil dan menurunkan persentase limfosit.

Tujuan dari penelitian ini adalah untuk mengetahui perlakuan manajemen pemberian pakan yang paling optimal dalam meningkatkan produktivitas ayam Buras Super melalui pengaturan frekuensi dan periode pemberian pakan. Hal tersebut dilihat dari status kesehatan ayam yang terdiri dari beberapa parameter yaitu glukosa, hemoglobin, rasio heterofil/limfosit, leukosit dan eritrosit.

\section{MATERI DAN METODE}

Materi yang dilakukan dalam penelitian ini adalah ayam 252 ekor anak ayam buras super unsex dengan rata-rata bobot badan 37,88 $\pm 1,98 \mathrm{~g}$ (CV : 5,02\%). Pakan yang digunakan adalah pakan komersial dari PT Charoen Pokphand. Penelitian ini menggunakan rancangan split plot design dengan main plot yaitu 3 taraf frekuensi pemberian pakan dan sub plot yaitu 3 taraf periode pemberian pakan dengan 4 ulangan sehingga menggunakan 36 unit percobaan 
dengan masing-masing unit percobaan berisi 7 ekor.

Tabel 1. Kandungan nutrien ransum dalam kering udara

\begin{tabular}{|c|c|c|}
\hline \multirow{2}{*}{ Kandungan Nutrien } & \multicolumn{2}{|c|}{ Ransum } \\
\hline & Starter & Finisher \\
\hline Protein Kasar $(\%)^{1)}$ & 21,02 & 20,44 \\
\hline Lemak Kasar (\%) & 6,71 & 4,03 \\
\hline Serat Kasar $(\%)^{1)}$ & 3,27 & 4,56 \\
\hline Kalsium $(\%)^{2)}$ & 1,00 & 0,82 \\
\hline Fosfor $(\%)^{2)}$ & 0,44 & 0,33 \\
\hline Kadar Air $(\%)^{1)}$ & 12,22 & 11,97 \\
\hline Kadar Abu $(\%)^{1)}$ & 6,96 & 7,01 \\
\hline Energi Metabolis $(\mathrm{kkal} / \mathrm{kg})^{3)}$ & 2.759 & 2.601 \\
\hline
\end{tabular}

1) Hasil Analisis Proksimat di Laboratorium Ilmu Nutrisi dan Pakan, Fakultas Peternakan dan Pertanian, Universitas Diponegoro (2017); ${ }^{2}$ Hasil Analisis Proksimat di Pusat Studi Pangan dan Gizi, Universitas Gadjah Mada, Yogyakarta (2017); ${ }^{3}$ Berdasarkan rumus Carpenter dan Clegg (1965) dalam Anggorodi $(1985) \mathrm{EM}(\mathrm{kkal} / \mathrm{kg})=40,81[0,87(\mathrm{PK}+2,25+\mathrm{LK}+\mathrm{BETN})+2,5]$.

Tabel 2. Perlakuan Frekuensi Pemberian Pakan dan Periode Pemberian Pakan

\begin{tabular}{|c|c|c|c|}
\hline \multirow[t]{2}{*}{ Perlakuan } & P1 $(08.00-22.00)$ & P2 $(06.00-22.00)$ & P3 $(04.00-22.00)$ \\
\hline & \multicolumn{3}{|c|}{ Jam pemberian pakan (WIB) dan porsi pemberian pakan (\%) } \\
\hline F1 & $08.00(100)$ & $06.00(100)$ & $04.00(100)$ \\
\hline \multirow[t]{2}{*}{ F2 } & $08.00(50)$ & $06.00(50)$ & $04.00(50)$ \\
\hline & $17.00(50)$ & $17.00(50)$ & $17.00(40)$ \\
\hline F3 & $\begin{array}{l}\text { 08.00(40), } \\
14.00(10), \\
17.00(50)\end{array}$ & $\begin{array}{l}06.00(40), \\
14.00(10), \\
17.00(50)\end{array}$ & $\begin{array}{c}04.00(40), \\
14.00(10), \\
17.00(50)\end{array}$ \\
\hline
\end{tabular}

Keterangan : P1 (periode 14 jam) ; P2 (periode 16 jam) ; P3 (periode 18 jam) ; F1 (frekuensi 1 kali) ; F2 (frekuensi 2 kali); F3 (frekuensi 3 kali)

Metode pengambilan data dilakukan pada minggu ke-8. Ayam dipuasakan terlebih dahulu selama \pm 6 jam sebelum sampel darah diambil. Sampel darah diambil sebanyak \pm 1 ml untuk tabung EDTA dan \pm 2 ml untuk tabung non EDTA dengan cara mengambil darah di bawah sayap (vena brachialis) menggunakan spuit. Sampel darah dimasukkan ke dua tabung yang berbeda yaitu tabung reaksi yang berisi anti koagulan Ethylene Diamine Tetra Acetic Acid (EDTA) dan tabung reaksi non EDTA. Sampel kemudian di analisis di Laboratorium RSH Universitas Gajah Mada. Data dianalisis dengan analisis ragam split plot design dan uji $\mathrm{F}$ pada taraf 5\%.

\section{HASIL DAN PEMBAHASAN}

\section{Pengaruh Perlakuan terhadap Glukosa}

Hasil penelitian pada Tabel 4 menunjukkan bahwa rata-rata glukosa darah pada masing-masing perlakuan yaitu 98,9375 - 170,25 mg/dL. Hasil tersebut lebih rendah dari penelitian Mahmud (2016) yang menyatakan bahwa kadar glukosa pada ayam Kampung Broiler berkisar antara 219 - 225 $\mathrm{mg} / \mathrm{dL}$. Hal tersebut dapat disebabkan oleh ayam Buras Super yang memiliki kemampuan adaptasi terhadap lingkungan lebih baik dari ayam tersebut. Selain itu Heat Stress Index yang di bawah 160 dengan paparan cekaman panas hanya 2 jam tidak menyebabkan 
terganggunya kadar glukosa darah. Altan et al. mempengaruhi profil darah ayam terutama (2000) menyatakan bahwa paparan temperatur glukosa. tinggi $\left(39^{\circ} \mathrm{C}\right)$ selama kurang dari 2 jam tidak

Tabel 3. Suhu, kelembaban dan Heat Stress Index (HSI) di dalam kandang

\begin{tabular}{ccccc}
\hline \multirow{2}{*}{ Waktu } & \multicolumn{2}{c}{ Suhu } & \multirow{2}{*}{ RH (\%) } & HSI \\
\cline { 2 - 3 } & ${ }^{\circ} \mathrm{C}$ & ${ }^{\circ} \mathrm{F}^{*}$ & & 129,1 \\
$4: 00$ & 23,5 & 74,4 & 54,7 & 134,3 \\
$6: 00$ & 24,0 & 75,1 & 59,1 & 148,8 \\
$8: 00$ & 27,1 & 80,8 & 68,0 & 156,4 \\
$10: 00$ & 30,6 & 87,1 & 69,3 & 142,2 \\
Rataan & 26,3 & 79,4 & 62,8 & 161,0 \\
$12: 00$ & 33,1 & 91,5 & 69,4 & 154,6 \\
$14: 00$ & 31,5 & 88,7 & 65,9 & 157,8 \\
Rataan & 32,3 & 90,1 & 67,6 & 153,0 \\
$17: 00$ & 27,9 & 82,3 & 70,8 & 151,7 \\
$18: 00$ & 28,1 & 82,6 & 69,1 & 152,4 \\
Rataan & 28,0 & 82,4 & 70,0 &
\end{tabular}

Keterangan $*{ }^{\circ} \mathrm{F}=\left(9 / 5 \mathrm{x}^{\circ} \mathrm{C}\right)+32^{\circ} \mathrm{C}$.

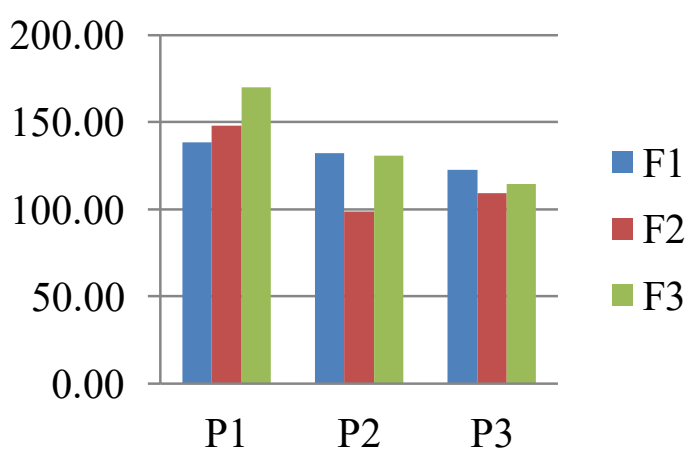

Gambar 1. Grafik glukosa

Hasil analisis statistik menunjukkan bahwa tidak ada pengaruh interaksi frekuensi pemberian pakan dengan periode pemberian pakan $(\mathrm{p}>0,05)$ terhadap glukosa darah, tetapi perlakuan periode berpengaruh nyata $(p<0,05)$ terhadap kadar glukosa darah ayam Buras Super. Tidak ada pengaruh interaksi perlakuan dikarenakan waktu nyaman ayam yang lebih panjang dari pada saat stress, sehingga kombinasi perlakuan frekuensi dan periode tidak berpengaruh pada glukosa darah. Mujahid (2011) menyatakan bahwa manajemen pemberian pakan diperlukan saat ayam terekspos pada temperatur tinggi untuk mengurangi peningkatan glukosa darah. Faktor periode yang memberikan pengaruh tertinggi adalah P1 yaitu 14 jam. Hal itu disebabkan ayam mampu mengatur kebutuhan energinya dengan baik sesuai dengan perlakuan manajemen yang diterapkan, sehingga periode penyajian ransum paling pendek memberikan hasil efesien untuk kadar glukosa. Diara dan Tabuaciri (2014) menyatakan bahwa ayam mampu beradaptasi dengan waktu penyajian ransum untuk mengatur konsumsi energi sehingga mempengaruhi kadar glukosa darah.

Pada tabel 4 menunjukkan semakin panjang periode pemberian pakan kadar glukosa memberikan efek menurunnya glukosa darah. Hal ini disebabkan semakin panjang periode pemberian pakan maka waktu makan ayam semakin panjang, lamanya waktu makan memberikan waktu nyaman yang lebih, 
sehingga ayam mampu mengkonsumsi pakan dengan leluasa, laju pakan rendah menjadikan kadar glukosa semakin turun. Ferket dan Gernat (2006) menyatakan bahwa ayam mampu mengatur konsumsi ransum dimana saat memerlukan energi untuk termoregulasi karena cekaman panas ayam akan mengurangi konsumsi akibat kadar glukosa di dalam darah tinggi dan glukosa dibawa aliran darah menuju ke hati.

Tabel 4. Rata-rata glukosa ayam buras Super tiap perlakuan umur $3-12$ minggu

\begin{tabular}{ccccc}
\hline Perlakuan & P1 & P2 & P3 & Rata-rata \\
\hline F1 & 138,74 & 132,34 & 122,59 & 131.22 \\
F2 & 148,29 & 98,94 & 109,52 & 118.91 \\
F3 & 170,25 & 130,83 & 114,58 & 138.55 \\
\hline Rata-rata & $152,42^{\mathrm{a}}$ & $120,70^{\mathrm{b}}$ & $115,56^{\mathrm{b}}$ & \\
\hline
\end{tabular}

Keterangan : Superskrip yang berbeda menunjukkan adanya perbedaan nyata $(\mathrm{P}<0,05)$

\section{Pengaruh Perlakuan terhadap Hemoglobin}

Hasil penelitian pada menunjukkan bahwa rata - rata kadar hemoglobin darah ayam buras super adalah $8,43-10,73 \mathrm{~g} / \mathrm{dL}$. Hasil tersebut tidak berbeda dengan penelitian Borges et al. (2004) yang menyatakan bahwa rataan kadar hemogoblin pada ayam adalah $8,75 \mathrm{~g} / \mathrm{dL}$. Hasil tersebut dipengaruhi oleh faktor temperature, kelembaban dan HSI. Saat temperature meningkat pada siang hari tetapi kelembaban tetap konstan mengakibatkan HSI berada dibawah 160. Hal itu memicu tidak terjadi peningkatan pada kadar hemoglobin. Rosita et al. (2015) menyatakan bahwa peningkatan hemoglobin terjadi seiring dengan peningkatan metabolisme tubuh sehingga saat stress hemoglobin akan meningkat untuk proses termoregulasi.

Tabel 5. Rata - rata hemoglobin ayam buras Super tiap perlakuan umur 3 - 12 minggu

\begin{tabular}{ccccc}
\hline Perlakuan & P1 & P2 & P3 & Rata-rata \\
\hline F1 & 8.93 & 9.15 & 9.88 & 9.32 \\
F2 & 10.73 & 8.95 & 8.43 & 9.37 \\
F3 & 9.88 & 9.80 & 9.43 & 9.70 \\
\hline Rata-rata & 9.84 & 9.30 & 9.24 & \\
\hline
\end{tabular}

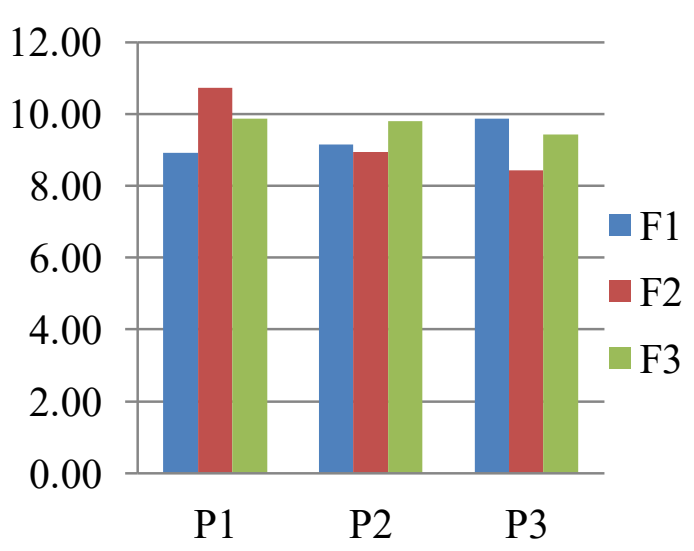

Gambar 2. Grafik Hemoglobin

Hasil analisis statistik menunjukkan bahwa tidak ada pengaruh interaksi frekuensi pemberian pakan dengan periode pemberian pakan $(p>0,05)$ terhadap kadar hemoglobin darah, demikian pula masing-masing perlakuan tidak berpengaruh nyata $(\mathrm{p}>0,05)$ terhadap hemoglobin darah ayam buras super. Kombinasi perlakuan tidak berpengaruh 
terhadap hemoglobin dikarenakan selama penelitian kondisi di dalam kandang termasuk comfort zone ayam. Hal tersebut berakibat pada tidak terganggunya fungsi hemoglobin dalam mengikat oksigen. Kusnadi (2009) menyatakan bahwa saat cekaman panas mengakibatkan turunnya kadar oksigen di dalam tubuh ayam sehingga memicu hemoglobin untuk memperbanyak diri. Frekuensi 1, 2 dan 3 kali dengan periode penyajian ransum 14 jam, 16 jam serta 18 jam tidak memberikan pengaruh terhadap kadar hemoglobin dikarenakan pengaturan pola manajemen pemberian pakan menjadi tidak berdampak ketika keadaan lingkungan dalam kondisi nyaman untuk ayam. Shariatmadari (2011) menyatakan bahwa perencanaan program pemberian pakan diperlukan memperhatikan fisiologi lingkungan seperti temperatur dan kelembaban.

\section{Pengaruh Perlakuan terhadap Rasio H/L}

Hasil penelitian pada Tabel 7 menunjukkan bahwa rasio heterofil-limfosit ayam buras super untuk masing-masing perlakuan berkisar 0,52-1,56. Hasil tersebut lebih tinggi dari penelitian Mahmud (2016) yang menyatakan bahwa rasio heterofillimfosit untuk ayam Kampong Broiler berkisar antara $0,73-0,84$. Hal itu diakibatkan oleh genetik dari ayam Buras Super yang berbeda dengan kampong broiler. Ayam Buras Super memiliki kemampuan lebih baik untuk beradaptasi dengan lingkungan tropis. Mahmoud dan Yassen (2005) menyatakan bahwa meskipun rasio $\mathrm{H} / \mathrm{L}$ merupakan indikator untuk respon terhadap heat stress, tetapi tidak menandakan bahwa respon terhadap kekebalan tubuh juga berbeda dimana genetik mempengaruhi hal tersebut.

Tabel 6. Rata - rata Rasio H/L Ayam Buras Super tiap Perlakuan umur 3 -12 minggu

\begin{tabular}{ccccc}
\hline Perlakuan & P1 & P2 & P3 & Rata-rata \\
\hline F1 & $0.98^{\mathrm{b}}$ & $1^{\mathrm{ab}}$ & $0.77^{\mathrm{b}}$ & 0.91 \\
F2 & $0.93^{\mathrm{b}}$ & $0.52^{\mathrm{b}}$ & $0.56^{\mathrm{b}}$ & 0.67 \\
F3 & $0.56^{\mathrm{b}}$ & $1.56^{\mathrm{a}}$ & $0.88^{\mathrm{b}}$ & 1.00 \\
\hline Rata-rata & 0.82 & 1.03 & 0.74 &
\end{tabular}

Keterangan : Superskrip yang berbeda pada baris yang sama menunjukkan perbedaan yang nyata $(\mathrm{P}<0,05)$

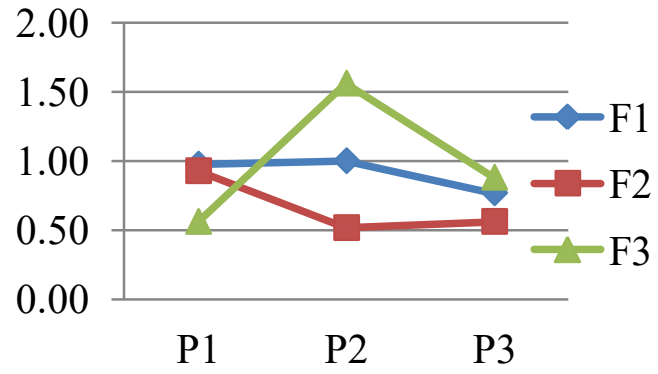

Gambar 3. Grafik Rasio Heterofil/Limfosit

Digambarkan pada ilustrasi 3 , periode 1 (14 jam) frekuensi 3 kali nilai rasio $\mathrm{H} / \mathrm{L}$ lebih rendah dibandingkan frekuensi 1 kali dan frekuensi 2 kali, pada periode 2 (16 jam) frekuensi 3 kali didapatkan nilai rasio $\mathrm{H} / \mathrm{L}$ paling tinggi dibandingkan frekuensi 1 kali dan frekuensi 2 kali, namun pada periode 3 (18 jam) semua frekuensi sama - sama menurun. Penurunan rasio $\mathrm{H} / \mathrm{L}$ pada periode 18 jam disebabkan oleh akses pakan yang panjang memberikan kesempatan makan pada ayam yang lebih lama sehingga ayam mampu mengatur konsumsi dengan santai. Keadaan 
kandang yang nyaman dengan indeks stress yang masih mampu ditolerir (Tabel 3 dan 4) mengakibatkan kondisi ayam selalu comfort zone. Turkyilmas (2008) melaporkan bahwa ratio $\mathrm{H} / \mathrm{L}$ merupakan indikator stress pada ayam dan $\mathrm{H} / \mathrm{L}$ akan mengalami peningkatan saat ayam terkena cekaman panas. Mahmoud dan Yaseen (2005) menyatakan bahwa kondisi ayam yang selalu dalam keadaan nyaman memicu rendahnya nilai $\mathrm{H} / \mathrm{L}$ dengan penurunan heterofil dan kenaikan limfosit. Frekuensi 2 kali pada periode 18 jam dengan kondisi kandang yang nyaman dan pemberian pakan pada waktu thermoneutral zone memicu tidak adanya kenaikan rasio $\mathrm{H} / \mathrm{L}$. Buyse dan Decuypere (2003) menyatakan bahwa menejemen pemberian pakan dengan frekuensi lebih dari 1 kali pada suhu dan kelembaban nyaman tidak akan memicu stress panas akibat penambahan beban panas tubuh.

Hasil analisis statistik menunjukkan bahwa terdapat pengaruh interaksi frekuensi pemberian pakan dengan periode pemberian pakan $(p<0,05)$ terhadap rasio $H / L$, tetapi masing-masing perlakuan tidak berpengaruh nyata $(p>0,05)$ terhadap rasio $\mathrm{H} / \mathrm{L}$ ayamburas super. Terdapat pengaruh interaksi terhadap rasio $\mathrm{H} / \mathrm{L}$ menunjukkan bahwa meskipun HSI masih mampu ditolerir oleh ayam karena dibawah 160, pengaturan frekuensi dan periode pada manajemen pemberian pakan berperan pada kondisi stress ayam. Kusnandi (2008) manyampaikan bahwa rasio $\mathrm{H} / \mathrm{L}$ dapat mengalami peningkatan saat kondisi cekaman panas karena akibat penurunan jumlah limfosit dalam usaha termoregulasi. Frekuensi pemberian pakan 3 kali dengan periode 16 jam memiliki nilai rasio $\mathrm{H} / \mathrm{L}$ tertinggi dikarenakan oleh adanya penambahan beban panas saat pakan diberikan pada siang hari, sehingga ayam melakukan usaha untuk menstabilkan suhu tubuh. Tamzil (2014) menyatakan bahwa saat cekaman panas terjadi gangguan pada selsel pembentukan energi akibat meningkatnya metabolisme dan berkurangnya oksigen sehingga menurunkan jumlah limfosit.

\section{Pengaruh Perlakuan terhadap Leukosit}

Hasil penelitian menunjukkan bahwa rataan leukosit pada ayam buras super adalah $7,88-21,33 \quad 10^{3} / \mu 1$. Hasil tersebut menunjukkan bahwa kadar leukosit termasuk dalam kisaran normal. Rentang nilai normal leukosit pada ayam adalah $7-3210^{3} / \mu 1$ (Coles, 2006). Leukosit merupakan indikator yang menunjukkan bahwa apakah ternak mengalami cekaman panas jangka panjang. Saat terkena cekaman panas sel-sel leukosit mengalami penuruan akibat terjadinya gangguan pemberntukan energi. Tamzil (2014) melaporkan bahwa saat comfort zone kadar leukosit pada ayam berkisar 7,31 $10^{3} / \mu \mathrm{l}$ dan mengalami penuruanan menjadi 4,38 $10^{3} / \mu 1$ saat cekaman panas. Leukosit dalam kisaran normal merupakan akibat dari HSI yang masih dibawah 160 sehingga sehingga selama penelitian kondisi lingkungan masih mampu ditolerir ayam. Salam et al. (2013) menyatakan bahwa kenaikan temperatur lingkungan mencapai 29 - $35{ }^{\circ} \mathrm{C}$ dan kelembaban 56 91\% menyebabkan terjadinya penurunan sel darah putih akibat heat stress.

Hasil analisis ragam menunjukkan bahwa tidak ada pengaruh interaksi frekuensi dan periode pemberian pakan $(p<0,05)$ maupun pengaruh masing-masing faktor terhadap kadar leukosit. Hal tersebut akibat dari selama penelitian paparan heat stress 
terjadi hanya 2 jam dan rentang comfort zone berlangsung 2 jam.

Tabel 7. Rata - rata leukosit ayam buras Super tiap perlakuan umur 3-12 minggu

\begin{tabular}{ccccc}
\hline Perlakuan & P1 & P2 & P3 & Rata-rata \\
\hline F1 & 12.23 & 17.8 & 16.75 & 15.59 \\
F2 & 7.88 & 21.325 & 18.20 & 15.80 \\
F3 & 17.43 & 16.55 & 17.10 & 17.03 \\
\hline Rata-rata & 12.51 & 18.56 & 17.35 & \\
\hline
\end{tabular}

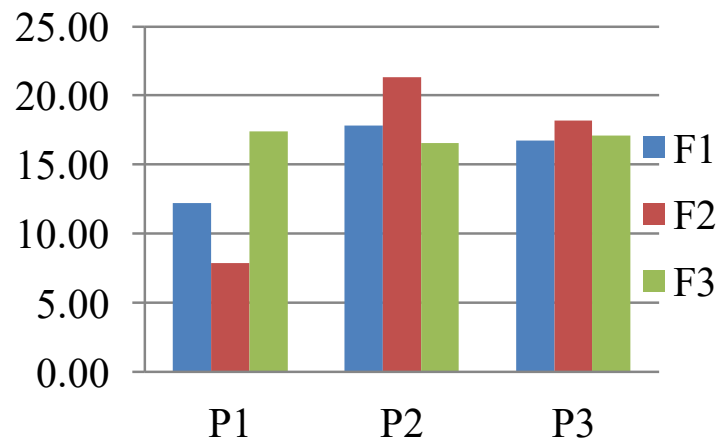

Gambar 4. Grafik Leukosit

Heat stress yang singkat mengakibatkan perlakuan frekuensi menjadi tidak berpengaruh akibat tidak adanya pembongkaran energi untuk pembuangan panas. Ransum dapat dimanfaatkan dengan baik pada waktu-waktu pemberiannya. Blahova et al. (2007) menyatakan bahwa temperatur lingkungan merupakan salah satu faktor penting yang dapat berpengaruh secara signifikan terhadap metabolisme tubuh ayam sehingga kenaikannya berdampak pula pada jumlah sel leukosit. Kang et al. (2011) melaporkan bahwa terjadi penuruanan kadar leukosit sebanyak $4 \%$ akibat stress panas dimana ayam tidak mampu berdaptasi terhadap penyajian ransum yang diberikan sehingga terjadi degradasi pada sel-sel darah putih. Faktor periode menjadi tidak berpengaruh akibat ayam dapat beradaptasi dengan baik terhadap panjang pendeknya periode karena selama penelitian
HSI masih dibatas toleransi untuk ayam. Elkheir et al. (2008) menyatakan bahwa ketika ayam terpapar heat stress yaitu pada suhu $35^{\circ} \mathrm{C}$ lebih dari 4 jam akses pakan selama 12 jam menjadi terganggu sehingga terjadi upaya pengualaran panas tubuh dan berakibat sel-sel darah putih mengalami penuruanan.

\section{Pengaruh Perlakuan terhadap Eritrosit}

Pengaruh perlakuan frekuensi pemberian pakan dan periode pemberian pakan terhadap eritrosit dapat dilihat pada Tabel 5. dan Gambar 5. Hasil penelitian menunjukkan rataan eritrosit ayam buras super berkisar 2,27 - 2,44 $\left(10^{6} / \mu \mathrm{L}\right)$. Hasil tersebut menunjukkan kisaran eritrosit dalam keadaan yang normal. Sriwati et al. (2005) yang menyatakan bahwa jumlah eritrosit berada pada kisaran normal yaitu $2,3-3,5 \times 10^{6} / \mu \mathrm{L}$. Hal ini terjadi karena kebutuhan pakan harian ayam tercukupi sehingga pembentukan eritrosit terjadi secara baik.

Eritrosit merupakan indikator tercukupinya nutrien dan nilai gizi yang didapat ayam melalui pakan yang dikonsumsi. Pada penelitian ini ayam terpapar panas paling lama berlangsung selama 2 jam dan suhu masih dibawah heat stress index (HSI) sehingga jumlah eritrosit didalam keadaan normal. Rosita et al. (2013) melaporkan bahwa 
jumlah eritrosit dan kadar hemoglobin akan dan akan menurun pada temperatur lingkungan meningkat pada temperatur lingkungan rendah yang tinggi.

Tabel 8. Rata - rata eritrosit ayam Buras Super tiap perlakuan umur 3 -12 minggu

\begin{tabular}{ccccc}
\hline Perlakuan & P1 & P2 & P3 & Rata-rata \\
\hline F1 & 2,19 & 1,985 & 2,40 & 2,19 \\
F2 & 2,79 & 2,1975 & 1,76 & 2,25 \\
F3 & 2,34 & 2,75 & 2,65 & 2,58 \\
\hline Rata-rata & 2,44 & 2,31 & 2,27 & \\
\hline
\end{tabular}

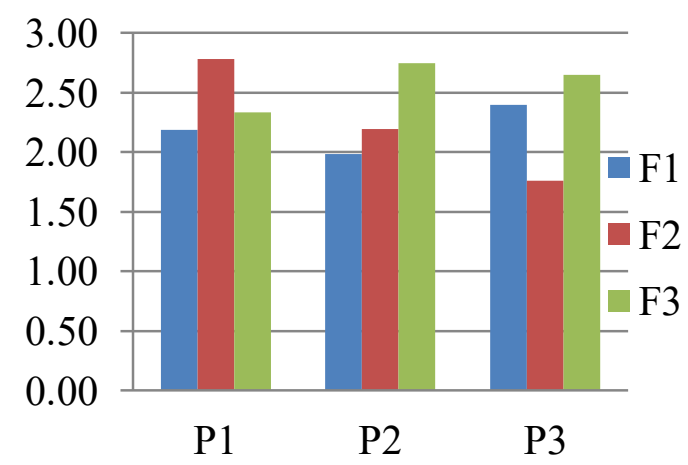

Gambar 5. Grafik Eritrosit

Fluktuasi temperatur pada siang hari tidak menyebabkan kadar eritrosit menjadi naik maupun turun karena ayam dapat beradaptasi secara baik tengan kondisi lingkungan yang masih dibawah HSI sehingga ayam dapat memenuhi kebutuhan nutrient dari pakan.Wardhana et al. (2001) menyatakan kurangnya prekusor seperti zat besi dan asam amino yang membantu proses pembentukan eritrosit akan menyebabkan penurunan jumlah eritrosit. Keadaan ini dapat disebabkan oleh gangguan penyerapan atau nilai gizi yang berkurang pada pakan yang diberikan sehingga akan mempengaruhi organ yang berperan dalam produksi sel darah. Semakin pendek periode pemberian pakan mengakibatkan jumlah eritrosit yang lebih tinggi dari periode lainnya. Hal ini disebabkan ayam memanfaatkan waktu yang singkat untuk mengkonsumsi pakan sehingga aktivitas makan ternak meningkat berdampak pada pembentukan eritrosit. Rosita et al (2013) menyatakan ternak yang banyak melakukan aktivitas akan memiliki jumlah eritrosit yang banyak pula, karena ternak akan mengonsumsi banyak oksigen. Jumlah eritrosit dipengaruhi oleh bangsa dan jenis ternak, jenis kelamin, umur, kondisi tubuh, variasi harian, kondisi nutrisi, aktivitas fisik, temperatur lingkungan dan keadaan stres (Swenson, 1984).

\section{KESIMPULAN}

Simpulan dari penelitian menunjukkan perlakuan periode 1 berpengaruh nyata terhadap kadar glukosa darah dengan nilai paling tinggi dibandingkan periode 2 dan periode 3 . Frekuensi 1, 2 dan 3 pada periode 3 terdapat pengaruh interaksi nyata dimana nilai rasio HL ayam buras super semakin membaik.

\section{DAFTAR PUSTAKA}

Abioja, M. O., G. O. Sodipe, A. J. Abiona, A. K. Oladipo, D. O. Kasali, Z. Akerele, A. Ola, H. Oke, O. Ogundele, dan A. O. Osinowo. 2014. Thermotolerance acquisition in broiler chickens through early feed restriction: response to acute heat stress. Pertanika. J. Trop. Agric. Sci. $37(3): 311-319$. 
Al-Aqil, A., I. Zulkifli, A. Q. Sazili, A. R. Omar dan M. A. Rajion. 2009. The effects of the hot, humid tropical climate and early age feed restriction on stress and fear responses, and performance in broiler chickens. Asian-Aust J. Anim. Sci. 22 (11) : 1581 - 1586.

Altan, O., A. Altan, M. Cabuk dan H. Bayragtar. 2000. Effects of heat stress on some blood parameters in broilers. Turk J. Vet. Anim. Sci. 24 (2) : $145-148$.

Blahova, J., R. Dobsikova, E. Strakova dan P. Suchy. 2007. Effect of low environmental temperature on performance and blood system in broiler chickens (Gallus domesticus). Acta Vet. Brno. 76 (8) : 17 - 23.

Borges, S. A., A. V. Fischer da Silva, A. Majorka, D. M. Hooge dan K. R. Cummings. 2004. Physiological responses of broiler chickens to heat stress and dietary electrolyte balance (sodium plus potassium minus chloride, milliequivalents per kilograms). Poult. Sci. 83 (9) : 1551 - 1558.

Buyse, J. and E. Decuypere. 2003. Feeding patterns in chickens : effect of endocrine and metabolic status. Proc. Aust. Poult. Sci. Sym. $15: 7-16$.

Coles, B. H. 2006. Essential of Avian Medicine Surgery. Iowa (US): Blackwell Pub.

Diarra, S. S. and P. Tabuaciri. 2014. Feeding management of poultry in high environmental temperatures. Int. J. of Poult. Sci. 13 (11) : 657 - 661.

Elkheir, S., M. K. Mohammed, M. M. Ahmed, and S. M. Abdelgadir. 2008. Effect of Feed Restriction and Ascorbic Acid Supplementation on Performance of Broiler Chicks Reared under Heat Stress. Research Journal of Animal and Veterinary Sciences. 3: 1-8.
Ferket, P. R. and A. G. Gernat. 2006. Factors that affect feed intake meat birds: a review. Int. J. Poult. Sci. 5 (10) : 905 911.

Filho, F., S. P. Rosa, S. B. Vieira, M. Macari and L. R. Furlan. 2005. Protein levels and environmental temperature effects on carcass characteristics, performance, and nitrogen excretion of broiler chickens from 7 to 21 days of age. Brazillian J. of Poult. Sci. 7 (4) : 247 253.

Kang, S., Y. Ko, Y. Moon, S. Sohn and I. Jang. 2011. Effects of the combined stress induced by stocking density and feed restriction on hematological and cytokine parameters as stress indicators in laying hens. Asian-Aust J. Anim. Sci. 24 (3) : $414-420$.

Kusnadi, E. 2009. Pengaruh berbagai cekaman terhadap perubahan beberapa komponen dan biokimia darah unggas. Prosiding Seminar Nasional Teknologi Peternakan dan Veteriner. Padang. Hal : $1-6$.

Kusnadi, E. 2009. Perubahan malonaldehida hati, bobot relatif bursa fabricius dan rasio heterofil/limfosit $(\mathrm{H} / \mathrm{L})$ ayam broiler yang diberi cekaman panas. Media Peternakan. 32 (2) : $81-87$.

Mahmoud, K. Z. dan A. M. Yaseen. 2005. Effect of feed withdrawal and heat acclimatization on stress responses of male broiler and layer type chickens (Gallus gallus domesticus). Department of Animal Production, Faculty of Agriculture, Jordan. 18 (10) : 1445 1450.

Mahmud, A. T. B. A. 2016. Profil Darah, Performa dan Kualitas Daging Ayam Persilangan Kampung Broiler (KB) Pada Kepadatan Kandang Yang Berbeda. Skripsi. Program Studi Ilmu Produksi dan Teknologi Peternakan, Fakultas Peternakan, Institut Pertanian Bogor. Bogor. 
Mujahid, A. 2011. Nutritional strategis to maintain efficiency and production of chickens under high environmental temperature. J. Poult. Sci. 48 (3) : 145 154.

Rachmawati, E., A. Mushawwir dan D. Latipudin. 2015. Profil glukosa dan kreatin darah darah ayam petelur fase layer pada temperature humidity index yang berbeda. Students e-Journal. 4 (1) : $1-12$.

Rosita, A., A. Mushawwir dan D. Latipudin. 2015. Status hematologis (eritrosit, hematokrit dan hemoglobin) ayam petelur fase layer pada temperature humidity index yang berbeda. Students e-Journal. 4 (1) : 1 - 10.

Salam, S., D. Sunarti dan Isroli. 2013. physiological responses of blood and immune organs of broiler chicken fed dietary black cumin powder (Nigella sativa) during dry seasons. J. Indonesian. Trop. Anim. Agric. 38 (3) : 185 - 191.

Shariatmadari, F. 2012. Plans of feeding broiler chickens. World's Poult. Sci. J. 68 (1) : 21 - 31.

Sriwati, D., E. Widodo. dan M. H. Natsir. 2005. Pengaruh penggunaan tepung jintan putih (Cuminum cyminum L.) dalam pakan terhadap profil darah ayam pedaging.

Fakultas

PeternakanUniversitas Brawijaya, Malang. 12 (1): 7-10

Swenson. 1984. Duke's Phisiology of Domestic Animals. Tenth edition. London. Cornel University Press. Tasse,
A. M., 2010. Tampilan Asam Lemak Dalam Susu Sapi Hasil Pemberian Ransum Mengandung Campuran Garam Karboksilat atau Metil Ester Kering. (Disertasi). Institut Pertanian Bogor. Bogor.

Tamzil, M. H. 2014. Stress panas pada unggas : metabolisme, akibat dan upaya penanggulangannya. Wartazoa. 24 (2) : $57-66$.

Toplu, H.D.O., A. Nazligul, S. Karaarslan, M. Kaya and O. Yagin. 2014. Effects of heat conditioning and dietary ascorbic acid supplementation on growth performance, carcass and meat quality characteristics inheat-stressed broilers. Ankara Univ. Vet. Fak. Derg. 61(4): 295-302.

Turkylmas, M. K. 2005. The effect of stocking density on stress reaction in broiler chickens during summer. Turk. J. Vet. Anim. Sci. 32 (1) : 31 - 36.

Wardhana, H., April., E. Kenanawati., Nurmawati., Rahmaweni., dan C. B. Jatmiko. 2001. Pengaruh pemberian sediaan patikaan kebo (Euphorbia hirta l) terhadap jumlah eritrosit, kadar hemoglobin, dan nilai hematokrit pada ayam yang diinfeksi dengan Eimeria tenella. J. Ilmu Ternak dan Veteriner. 6 (2) :1-6.

Zulkifli, I., M. T. Che Norma, D. A. Israf, dan A. R. Omar, 2000. The effect of early age feed restriction on subsequent response to high environmental temperatures in female broiler chickens. Poult. Sci. 79 (10) : 1401-1407. 